\title{
ІНФОРМАЦІЙНІ ТЕХНОЛОГІЇ АВТОМАТИЗОВАНОГО ПРОЕКТУВАННЯ ПРИЛАДІВ І СИСТЕМ МЕДИКО-БІОЛОГІЧНОГО ПРИЗНАЧЕННЯ
}

\author{
В. О. Романов, І. Б. Галелюка, О. В. Вороненко \\ Інститут кібернетики імені В. М. Глушкова НАН України
}

\begin{abstract}
It is described information technology for computer-aided design of computer devices and systems, developed in V.M.Glushkov Institute of Cybernetics of NAS of Ukraine. The information technology is worth to be used on the stage of the requirements specification or EFT-stage, because it gives the possibility of fast estimating of the project realization, certain characteristics and, as a result, expected benefit of its applications. Using of this technology already increases automation level of design stages of new devices for different purposes. Proposed information technology gives possibility to specialists of such scientific fields, as medicine, biology, biochemistry, physics etc, to check possibility of device creating on the basis of developed sensors.
\end{abstract}

Досягнення науки і техніки за останнє століття привели до бурхливого розвитку багатьох галузей діяльності людини, включаючи медицину. Саме тому на сьогодні багато діагностичних і лікувальних методик базується на використанні сучасного медичного обладнання. Дуже часто на практиці взагалі не можливо обійтися без використання багатьох вимірювальних медичних приладів. Революційні зміни в медицині відбуваються з наголосом на використанні новітніх комп'ютерних та інформаційних технологій, нових апаратних рішень в областях, які досі вважалися достатньо консервативними.

Щоб лікування хвороби було ефективним і дало позитивний результат, необхідно своєчасно і вірно встановити діагноз. Мало який фахівець зможе це зробити при одному тільки огляді. Тому навіть досвідчений і кваліфікований лікар у своій роботіповинен не тільки керуватися своїми знаннями, а й спиратися на сучасні технології, зокрема на різноманітні діагностичні та вимірювальні прилади і системи. Від того, наскільки якісно, точно і оперативно будуть проведені аналізи та опрацьовані отримані результати, залежить правильність призначеного лікування та його ефективний результат.

В медицині майбутнього важливу роль відводять не лікуванню захворювань, а їх профілактиці та ранньому прогнозуванню. Стрімкий розвиток отримує впровадження сучасних діагностичних та вимірювальних приладів. Але не дивлячись на швидке впровадження нових технологій, прямий контакт лікаря і пацієнта в багатьох випадках $є$ дуже важливим. Особливо гостро постає проблема спілкування у випадку, коли пацієнт обмежений у можливостях спілкування при тяжких захворюваннях, наприклад, інсульті. Отже, крім впровадження новітніх медичних приладів і систем постає гостра проблема в розробці та впровадженні нових інформаційних технологій для полегшення спілкування пацієнтів 3 порушенням функцій мовлення.
Багато приладів відомі нам 3 дитинства і часто використовуються не тільки в стінах лікувальних закладів, але і у домашніх умовах. До них можна віднести термометри, глюкометри, тонометри, кардіографи тощо. Якщо в побуті більшість приладів являють собою портативні взірці, орієнтовані на швидке застосування пересічним користувачем без спеціальних медичних знань, то в лікарнях та інших медичних закладах прилади та системи медичного призначення $€$ достатньо складним обладнанням з великою кількістю можливих режимів роботи, для обслуговування якого потрібен висококваліфікований персонал.

3 точки зору теорії автоматизованого проектування, усі побутові та спеціалізовані медичні прилади і системи об'єднує одна особливість - усі вони можуть бути представлені як стандартні вимірювальні канали, які складаються з сенсора, аналогової, аналогоцифрової та цифрової частин. Основу сучасних вимірювальних каналів складає ланцюг послідовно з'єднаних вимірювальних перетворювачів, включаючи сенсор, що безпосередньо сприймає вимірювальний сигнал. Слід зауважити, що традиційний вимірювальний канал складається $з$ стандартних компонентів, інтерфейсів та узгоджуючих засобів, які дозволяють нормалізувати сигнали від сенсора до вигляду, зручного для передачі в комп'ютер або мікроконтролер через систему стандартних інтерфейсів.

3 нашої точки зору, замість універсальних вимірювальних каналів, зокрема в медицині, доцільно будувати спеціалізовані канали без використання проміжних узгоджуючих вузлів і перетворювачів рівнів інформаційних сигналів, тобто число компонентів на шляху передачі сигналу від сенсора до мікроконтролера повинно бути мінімальним. Це може привести до того, що для кожного сенсора або групи сенсорів потрібно проектувати свій спеціалізований вимірювальний канал. У такому випадку елементна база,

(c) В. О. Романов, І. Б. Галелюка, О. В. Вороненко 
яка буде використовуватися, повинна мати властивості “м'якого" (програмного) продукту. Окремі компоненти повинні мати можливість конфігурування під конкретну задачу (прикладом можуть слугувати програмовані логічні інтегральні схеми). Саме для таких вимірювальних каналів потрібно мати системи автоматизованого проектування (САПР), якими могли б користуватися безпосередньо розробники сенсорів, а також ті, хто з допомогою цих пристроїв автоматизує процеси досліджень, контролю і керування (медики, біологи, хіміки тощо).

На сьогодні існує багато ефектів і явищ, а також відповідних сенсорів, на основі яких в Україні можна створювати медичні прилади або системи із заданими функціями. Вартість таких приладів при серійному виробництві була б значно меншою, ніж вартість закордонних аналогів. Але проблема полягає в тому, що науково-дослідні установи або окремі дослідники, які вивчили певний ефект чи явище і створили сенсор на його основі, не володіють знаннями щодо доведення результатів своїх досліджень до комерційного серійного приладу. Відсутність таких знань приводить до того, що розробник сенсора відкладає створений ним сенсор “у шухляду” і переключається на розв'язання іншої наукової задачі, хоча шлях від науково-дослідної розробки до серійного виробу чітко регламентований і давно вже пройдений низкою вітчизняних організацій. Тим не менш, на етапі створення дослідного взірця втрачається левова частина результатів вітчизняних досліджень в області нових сенсорів.

Оптимальним рішенням описаної вище проблеми було б створення на основі інформаційних технологій спеціального програмно-апаратного інструментарію, за допомогою якого розробник сенсора зміг би перевірити і оцінити можливість створення нового приладу на базі розробленого ним сенсора, попередньо розрахувати і оцінити характеристики приладу (наприклад, ціну, швидкодію, достовірність, розміри, надійність тощо), а в певних випадках і економічний ефект від реалізації проекту. Цей інструментарій повинен надавати можливість створення набору досить простих моделей такого приладу (функціональну, електричну, надійнісну, експлуатаційну тощо), включаючи попередній розрахунок параметрів, проект друкованої плати і комплект конструкторської документації. Вхідними даними такої системи проектування $\epsilon$ формалізований опис сенсора або його модель. Як було вказано вище, більшість приладів мають однакову структуру, а саме, вони складаються 3 сенсора, вимірювального каналу, процесорного вуз- ла обробки даних, інтерфейсу, засобів відображення іпередачі даних, блоку живлення і допоміжних вузлів. Тому процес проектування можна досить просто узагальнити і формалізувати.

Для розв'язання цієї задачі в Інституті кібернетики імені В. М. Глушкова Національної академії наук України розроблено інформаційні технології для автоматизованого проектування портативних приладів і засобів комп'ютерної техніки різноманітного призначення. В основу роботи інформаційних технологій покладено так звані віртуальні методи проектування або CAD/CAM-технології з орієнтацією на міждисциплінарні та трансдисциплінарні дослідження.

Основним призначенням запропонованих інформаційних технологій є забезпечення підтримки проектування нових комп'ютерних приладів і пристроїв різноманітного призначення на сучасній мікроелектронній елементній базі.

У загальному вигляді розроблені інформаційні технології автоматизованого проектування являють собою деяке інформаційне середовище, яке дозволяє проводити експерименти у випадку, коли немає безпосереднього доступу до об'єкта дослідження. При цьому експерименти можуть проводитися як 3 використанням математичних моделей, тобто в рамках одного комп'ютера, так і в разі можливості з використанням віддаленого доступу до об'єкту дослідження.

Запропоновані інформаційні технології автоматизованого проектування перевірені на реальних проектах Інституту кібернетики імені В. М. Глушкова НАН України, зокрема при розробці приладів медичного та агробіологічного призначення. Прилад для експрес-діагностики стану біологічних об' єктів (рослинних об'єктів) був доведений до серійного випуску і на даний час випускається серійно на сучасному контрактному виробництві. Також за допомогою розроблених інформаційних технологій був доведений до дослідного взірця прилад для експрес-діагностики гострих вірусних інфекцій, який працює на основі поверхневого плазмонного резонансу. Цей прилад успішно пройшов випробування в профільних організаціях на модельних розчинах.

Слід зауважити, що запропоновані інформаційні технології автоматизованого проектування можна використовувати не тільки для розробки нових приладів $\mathrm{i}$ систем різного призначення, але і для супроводження розробки нових технологій. Прикладом може слугувати розробка нової оригінальної технології спілкування 3 пацієнтами, які мають мовні обмеження. Вказана технологія складається з стандартних апаратних рішень і спеціально розроблених програмних 
засобів, які в сукупності розв'язують поставлену прикладну задачу, а саме полегшують спілкування лікаря з пацієнтами, що мають порушення функцій мовлення.

Запропонований підхід за рахунок впровадження інформаційних технологій автоматизованого проектування дозволить, на нашу думку, у перспективі наповнити ринок України вітчизняними портативними комп'ютерними приладами і системами різного призначення. Для цього, по-перше, слід формалізувати ефекти та явища, які передбачається покласти в основу нових портативних приладів, наприклад, для ідентифікаціїгострих інфекційних захворювань тощо. По-друге, слід впровадити методи автоматизованого проектування, включаючи навчальні демонстраційні версії п приклади їх використання, в наукових установах $з$ таких предметних галузей, як медицина, біохімія, фізіологія, екологія тощо. Це дозволить швидко доводити науково-дослідні розробки до комерційного продукту шляхом організації колективного доступу розробників сенсорів до інформаційних технологій автоматизованого проектування з бібліотеками типових рішень, прикладних програм, відповідними базами даних і знань. 